\title{
Phosphorylation and biosynthesis of high molecular weight proteins of tumor nuclear matrix
}

\author{
BAZARNOVA TM, TV BULDYAEVA, LS FILA- \\ TOVA, SB AKOPOV, IB ZBARSKY* \\ NK Koltzov Institute of Developmental Biology, Russian \\ Academy of Sciences, 26 Vavilov Street, 117344 Moscow, \\ Russia
}

\begin{abstract}
Our previous studies showed a predominance of high molecular weight protein group in tumor nuclear matrices. Contrary to normal cells, proteins of this group are preferentially phosphorylated. Phosphoproteins of hepatoma nuclear matrix are selectively subjected to rapid proteolysis. By alkali treatment and a monoclonal antibody against phosphotyrosyl residue the presence of two high molecular weight bands of phosphotyrosyl-containing proteins was detected in nuclear matrices of tumor but not of normal liver cells. High molecular weight protein group of tumor nuclear matrices revealed also a rapid turnover and preferential incorporation of labeled amino acids selectively inhibited by chloramphenicol.
\end{abstract}

Key words: Tumors, nuclear matrix, phosphoproteins, phosphotyrosine, nuclear protein biosynthesis.

\section{INTRODUCTION}

As early as in 1948 we have fractionated isolated nuclei from normal and tumor cells by extraction with $1 \mathrm{M} \mathrm{NaCl}$ and dilute alkali[1]. The nuclear residue was then studied more thoroughly[2,3]. Later on, similar proteinous nuclear residues were isolated by other workers[4-6] and as studied in 1974 termed "nuclear matrix" [7]. The nuclear matrix (NM) consists of numerous proteins but only few of them have been characterized.

\footnotetext{
* Corresponding author
} 
Phosphoproteins of tumor nuclear matrix

In studying the tumor NM it was found that it differed from normal quiescent as well as proliferating counterparts by a predominance of high molecular weight protein group (HMW) which was especially prominent in solid tumors[8, 9]. It is clearly seen by comparing the NM protein electropherograms of solid rat hepatoma and normal liver (Figs 1 and 2).

$\triangleright$ Fig 1. Electropherograms of lane 1-rat solid hepatoma 27 and lane 2-rat liver NM proteins in $7.5 \%$ SDS-PAG. Coomassie blue R-250 staining. Molecular mass standards: bovine serum albumin $(68 \mathrm{kD})$ and ovalbu$\min (43 \mathrm{kD})$.

$\triangleright$ indicating two most prominent bands of high molecular weight proteins of hepatoma nuclear matrix

$\mathbf{k D}$
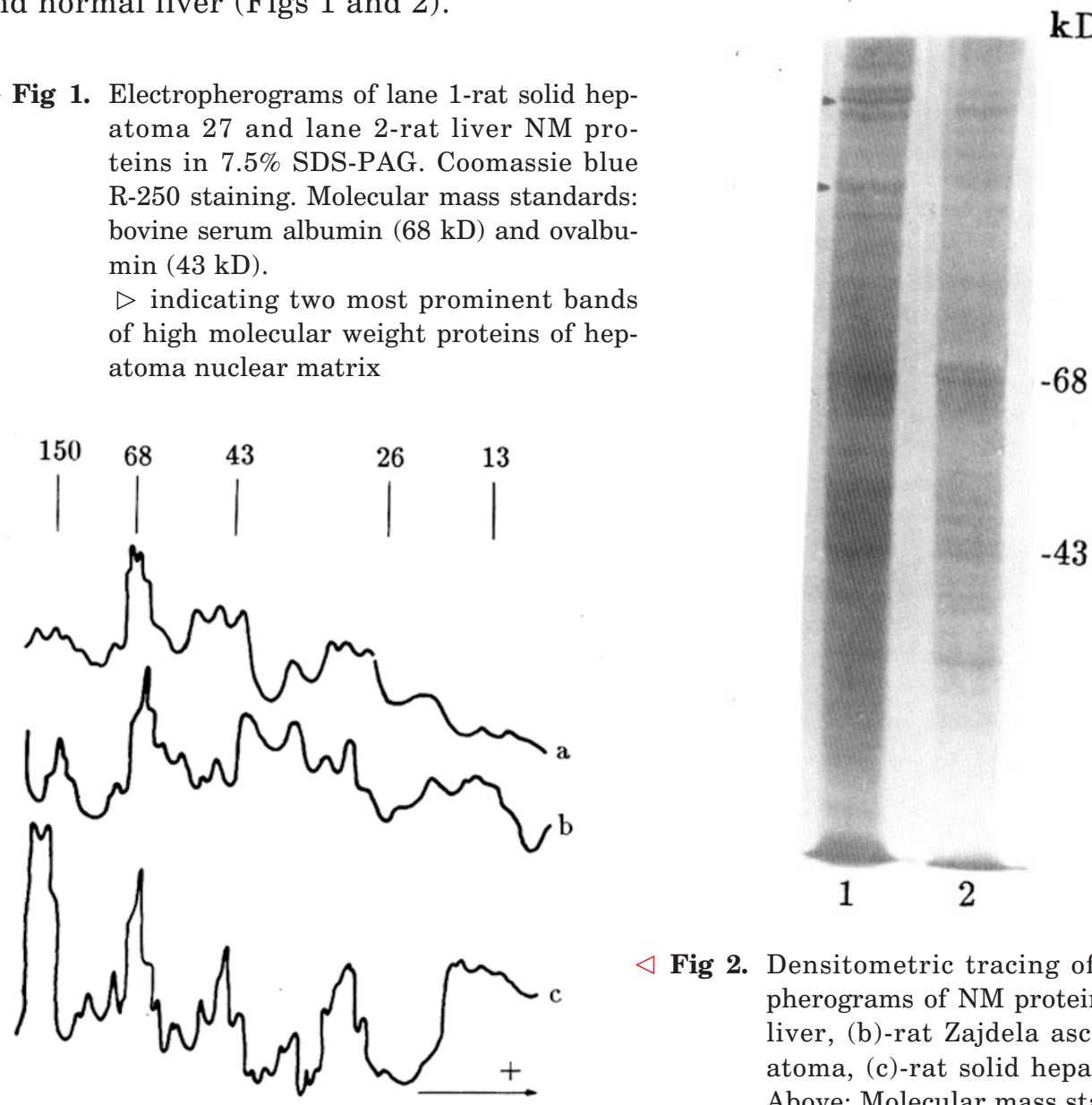

$\triangleleft$ Fig 2. Densitometric tracing of electropherograms of NM proteins (a)-rat liver, (b)-rat Zajdela ascites hepatoma, (c)-rat solid hepatoma 27. Above: Molecular mass standards.

These HMW proteins of tumor NM contain an abundance of DNA-topoisomerase II, nuclear pore glycoproteins and some other polypeptides characteristic of proliferating tissue. However, the presence of e.g. fibronectin in nuclei and NMs may be a specific feature of malignant cells $[10,11]$.

Numerous studies show that nuclear proteins[12], especially those of the NM, are phosphorylated more intensely in proliferating and still more in tumor cells[13, 14]. However, the protein kinases[15], comprising those phosphorylating by tyrosyl residue[16], were studied mostly in cytoplasm. Meanwhile, protein kinases are present inside the nuclei[17]; NM is rich in enzymes[18] and protein kinases have been found to be associated with the $\mathrm{NM}[14,19]$. 


\title{
MATERIALS AND METHODS
}

\author{
Animals, tumors and cell culture
}

Wistar male rats weighing 100 to $150 \mathrm{~g}$ and adult F1 mice of CBA x C57BL/6 strain were used. Transplantable solid rat hepatoma 27, rat Zajdela ascites hepatoma, mice ascites Ehrlich carcinoma and hepatoma 22a as well as HeLa cells grown in 199+MEM medium containing $10 \%$ fetal bovine serum at the 4 th passage in stationary phase were used as tumor materials.

\section{Isolation of cell nuclei and nuclear matrix}

Liver and hepatoma 27 cell nuclei were isolated according to Blobel and Potter[20] with our modification[9]. Briefly, freshly excised liver or tumor tissues taken 2-3 weeks after transplantation were minced and then homogenized in a Potter-Elvehjem homogenizer with 9 volumes of 0.25 M sucrose containing $3 \mathrm{mM} \mathrm{CaCl}_{2}$ filtered successively through 4 and 8 layers of gauze, and centrifuged at $1,000 \mathrm{~g}$ for $10 \mathrm{~min}$. The pellet diluted with $2.3 \mathrm{M}$ sucrose containing $1.5 \mathrm{mM} \mathrm{CaCl}_{2}$ was again homogenized for $5 \mathrm{~s}$, overlaid with the same solution of $2.3 \mathrm{M}$ sucrose and $1.5 \mathrm{mM} \mathrm{CaCl}_{2}$, and centrifuged at $50,000 \mathrm{~g}$ for $50 \mathrm{~min}$. The nuclear pellet was repeatedly washed by resuspending in $0.25 \mathrm{M}$ sucrose and centrifugation at $200 \mathrm{~g}$ for $10 \mathrm{~min}$. Tumor mince was preliminarily triturated in a homogenizer with a clearance of $0.5 \mathrm{~mm}$ and homogenized somewhat longer than liver.

Ascites cells of Ehrlich carcinoma and mouse hepatoma 22a sedimented by centrifugation were suspended and incubated in distilled water. After destruction by osmotic shock the cells were ground in a Potter-Elvehjem homogenizer and centrifuged at $800 \mathrm{~g}$. Then, the nuclear pellet was resuspended in 1.8 $\mathrm{M}$ sucrose and sedimented at 20,000 g. Zajdela ascites hepatoma cells were sedimented by centrifugattion, resuspended in $0.32 \mathrm{M}$ sucrose containing $3 \mathrm{mM} \mathrm{CaCl}_{2}$ and $0.1 \%$ of Triton X-100 and then homogenized in a Potter-Elvehjem homogenizer with a tight pestle. After $25 \mathrm{~min}$ incubation in this solution, the crude nuclei were sedimented at $500 \mathrm{~g}$ for $10 \mathrm{~min}$. The pellet was suspended in $2.3 \mathrm{M}$ sucrose containing $1.5 \mathrm{mM} \mathrm{CaCl}_{2}$, overlaid with the same sucrose solution and centrifuged at 50,000 g for $40 \mathrm{~min}$. Isolated nuclei were washed with $0.25 \mathrm{M}$ sucrose containing $3 \mathrm{mM} \mathrm{CaCl}_{2}$.

Nuclei from HeLa cells were isolated using the method of Wold et al.[21]. The cells in stationary (lag) phase were sedimented at $600 \mathrm{~g}$ for $4 \mathrm{~min}$ and washed by suspension in isotonic buffer containing $20 \mathrm{mM}$ Hepes $\mathrm{pH} 7.8 ; 1.5 \mathrm{mM} \mathrm{MgCl}_{2}$; $1 \mathrm{mM}$ DTT; $0.1 \mathrm{mM}$ PMSF; $5 \mathrm{mM} \mathrm{KC} 1$ and $0.25 \mathrm{M}$ sucrose, diluted with the buffer until $5 \times 10^{6}$ cells $/ \mathrm{ml}$ and centrifuged at $600 \mathrm{~g}$ for 3 min. Then, the washed cells were resuspended till $7 \times 10^{7}$ cells $/ \mathrm{ml}$ in the same buffer made hypotonic by exclusion of sucrose and left on ice for $15 \mathrm{~min}$. Swelling cells were lysed in an ice-cooled tight Dounce homogenizer by 10 strikes and then left for $30 \mathrm{~min}$. The nuclear pellet sedimented at 1,700 $\mathrm{g}$ for $10 \mathrm{~min}$ was washed by the above isotonic buffer and centrifuged at $600 \mathrm{~g}$ for $5 \mathrm{~min}$.

The NM was isolated from tumor or liver nuclei by the method of Herlan and Wunderlich[22]. modified only by the use of $0.5 \%$ (instead of $0.1 \%$ ) Triton X-100. Briefly, the nuclei were treated with Triton X-100 (Merck, Darmstadt, FRG) and then digested with 20-30 $\mu \mathrm{g} / \mathrm{ml}$ DNase I (Worthington, USA) and the same quantity of RNase A (Reanal, Budapest, Hungary) in $20 \mathrm{mM}$ Tris-HCl buffer A pH 7.4 containing $0.2 \mathrm{M}$ sucrose, $3 \mathrm{mM} \mathrm{CaCl}_{2}$, and $2 \mathrm{mM} \mathrm{MgCl}_{2}$. Digestion in the presence of $50 \mathrm{mM} \mathrm{NaCl}$ was proceeded at $30^{\circ} \mathrm{C}$ for $60 \mathrm{~min}$. Then $\mathrm{NaCl}$ was added to $2 \mathrm{M}$ concentration and incubated for $10 \mathrm{~min}$ for chromatin extraction. The nuclear residue was again treated with nucleases and washed with the same buffer A.

\section{Electrophoresis}

The proteins were separated by slab or disc gel electrophoresis in polyacrylamide gel (PAG) containing $0.1 \%$ SDS (Serva, Heidelberg, FRG)[23]. The samples of about $150 \mu \mathrm{g}$ protein were dissolved in $0.05 \mathrm{M}$ Tris- $\mathrm{HCl}$ buffer $\mathrm{pH} 6.8$ containing $2 \%$ SDS, $12 \%$ glycerol and 5\% B-mercaptoethanol at $100{ }^{\circ} \mathrm{C}$ for $5 \mathrm{~min}$. The dissolved samples were overlaid on concentrating gel comprising $2.5 \%$ acry- 


\section{Phosphoproteins of tumor nuclear matrix}

lamide, 0.6\% methylene-bis-acrylamide (both Reanal, Budapest, Hungary), 20\% sucrose, and $2 \%$ SDS. The resolving gel consisted of 12,10 or $7.5 \%$ acrylamide, $0.3 \%$ methylene-bis-acrylamide, and $0.1 \% \mathrm{SDS}$ in $0.43 \mathrm{M}$ Tris-HCl buffer, $\mathrm{pH}$ 8.9. The electrophoresis was performed at $4^{\circ} \mathrm{C}$ in 0.033 M Tris-HC1 buffer, pH 8.3, containing 0.6 M glycine and 0.1\% SDS with a current of $10 \mathrm{~mA}$ per slab until the leading stain entered into the separating gel and $40 \mathrm{~mA}$ until the stain passed to 10 $\mathrm{cm}$. The gels were fixed in ethanol:water:acetic acid $(4.5: 4.5: 1 \mathrm{v} / \mathrm{v})$ for $18 \mathrm{~h}$, stained with $0.125 \%$ Coomassie blue R-250 (Serva, Heidelberg, FRG), dissolved in the same mixture and destained by $7 \%$ acetic acid.

\section{Incubation with radioactive amino acids or phosphorus}

Zajdela ascites hepatoma (about $10^{8}$ cells $/ \mathrm{ml}$ ) cells were incubated in ascitics fluid at $30^{\circ} \mathrm{C}$ for $10 \mathrm{~min}$. Then chloramphenicol (CAL) $(100$ or $200 \mu \mathrm{g} / \mathrm{ml})$ or the same amount of alcohol (in control samples) was added. In $15 \mathrm{~min},\left[{ }^{14} \mathrm{C}\right]$-Clorella protein hydrolysate $(1 \mu \mathrm{Ci} / \mathrm{ml})$ was introduced. After 30 min the incubation was stopped by addition of double volume of ice-cold sucrose containing 3 $\mathrm{mM} \mathrm{CaCl}{ }^{2}$ and a mixture of non-labeled amino acids in 50-fold concentration. Initial concentration of radioactive amino acids was $25 \mathrm{uM}$. Thus, 50 fold concentration of non-labeled amino acids corresponded to $1.25 \mathrm{mM}$. The cells were sedimented, washed and used for nuclei and nuclear matrix isolation.

HeLa cell monolayers in Hanks solution depleted of methionine, instead of growth medium, were preincubated at $37^{\circ} \mathrm{C}$ with CAL $(100 \mu \mathrm{g} / \mathrm{ml})$ or equal volume of alcohol for $15 \mathrm{~min}$, then [ $\left.{ }^{35} \mathrm{~S}\right]$ methionine $(2,5 \mu \mathrm{Ci} / \mathrm{ml})$ was added, incubation was prolonged for another $60 \mathrm{~min}$. and stopped by immersing into an ice bath.

Phosphorylation in isolated nuclei was proceeded in a buffer containing $30 \mathrm{mM}$ Tris- $\mathrm{HCl} \mathrm{pH} \mathrm{7.5,}$ $120 \mathrm{mM} \mathrm{KCl}, 5 \mathrm{mM} \mathrm{MgCl}_{2}$ and $5 \mathrm{mM}$ dithiothreitol with $2.5 \mu \mathrm{Ci} / \mathrm{ml}$ of inorganic ${ }^{32} \mathrm{P}$ or of the $\mathrm{NM}$ with $2.5 \mu \mathrm{Ci} / \mathrm{ml}$ of $\gamma-{ }^{32} \mathrm{P}$-ATP at $30{ }^{\circ} \mathrm{C}$ for $30 \mathrm{~min}$. Details are described in legends to table and figures.

\section{Radioactivity measurement and autoradiography}

To measure the radioactivity of protein fractions the gels were cut to 48 or 30 equal slices. Each slice was put in a vial and eluted with $1 \mathrm{ml}$ of $0.5 \mathrm{~N} \mathrm{NaOH}-3 \% \mathrm{SDS}$ at $60^{\circ} \mathrm{C}$ for $18 \mathrm{~h}$. The eluate was neutralised with a few drops of $2.5 \mathrm{~N} \mathrm{HCl}$ to $\mathrm{pH} 7.0$, then $10 \mathrm{ml}$ dioxane was added and the radioactivity was measured by a liquid scintillation spectrometer "Intertechnique SL-30". Radioactivity of tissue homogenates, isolated nuclei and nuclear matrices was measured with the same scintillation spectrometer by applying of a sample on a $10 \mathrm{x} 10 \mathrm{~mm}$ piece of Whatman 3 MM paper in liquid toluene scintillator and represented in counts per minute per mg protein. For fluorography the gels were dried in vacuum and exposed with X-ray film at $-70{ }^{\circ} \mathrm{C}[24]$.

\section{Immunoblotting}

The proteins were electrotransferred from PAG to nitrocellulose filters[25] and treated with mouse monoclonal antibody to phosphotyrosyl containing protein. Then the antigens were revealed with monoclonal antibody IgG against mouse immunoglobulin conjugated with peroxidase. The transfer of proteins to nitrocellulose filters was controlled by staining with $0.1 \%$ amido black.

\section{Protein determination}

The protein content was measured by the method of Lowry et al.[26].

\section{RESULTS}

\section{Phosphorylation of nuclear matrix proteins}

The proteins of isolated rat hepatoma $27 \mathrm{NM}$ were intensely phosphorylated by 
NM-associated protein kinases followed by rapid dephosphorylation. Thus, in 15 30 min about half and in 1-2 h only $20 \%$ of initial radioactivity remained (Tab 1 ).

\section{Tab 1. Turnover of rat solid hepatoma 27 nuclear matrix phos- phoproteins \\ Isolated hepatoma 27 nuclear matrix proteins, preincubated in a buffer containing $30 \mathrm{mM}$ Tris-HC1, pH 7.5, $120 \mathrm{mM} \mathrm{KC1,} 5 \mathrm{mM}$ $\mathrm{MgCl}_{2}$ and $5 \mathrm{mM}$ dithiothreitol with $2.5 \mu \mathrm{Ci} \quad \gamma-\left[{ }^{32} \mathrm{P}\right]-\mathrm{ATP}$ at $30{ }^{\circ} \mathrm{C}$ for $20 \mathrm{~min}$, were postincubated in the same buffer without $\gamma-\left[{ }^{32} \mathrm{P}\right]$ ATP.}

\begin{tabular}{|c|c|c|c|c|}
\hline Experiment & $\begin{array}{c}\text { Initial activity } \\
\text { cpm }\end{array}$ & $\begin{array}{c}\text { Incubation } \\
\text { without }{ }^{32} \mathrm{P} \\
\text { min }\end{array}$ & $\begin{array}{c}\text { Postincubation } \\
\text { radioactivity } \\
\text { cpm }\end{array}$ & $\begin{array}{c}\text { Residual } \\
\text { radioactivity } \\
\%\end{array}$ \\
\hline 1 & 63,440 & 15 & 34,680 & 54.6 \\
\hline 2 & 47,820 & 30 & 22,530 & 47.0 \\
\hline 3 & 44,060 & 60 & 9,160 & 21,0 \\
\hline 4 & 52,720 & 120 & 10,180 & 20.0 \\
\hline
\end{tabular}

Then we incubated solid rat hepatoma 27 isolated nuclei with ${ }^{32} \mathrm{P}$ at $30{ }^{\circ} \mathrm{C}$ for $30 \mathrm{~min}$, separated the proteins of the isolated NM by electrophoresis in $7.5 \%$ SDSpolyacrylamide gel and visualized the radioactivity by autoradiography. When the isolation of the NM was proceeded in the presence of serine phosphatase inhibitors PMSF and DTNB, $1 \mathrm{mM}$ each, the radioactivity was detected preferentially in high molecular weight region (Fig 3A, lane 1). Thus, mainly HMW NM proteins were phosphorylated.

However, when the NM was isolated without inhibitors (Fig 3A, lane 2) the radioactivity was shifted to low molecular weight (LMW) area which meant an intense proteolysis of HMW phosphoproteins. The proteolysis comprised phosphoproteins selectively for a comparison of both lanes stained with Coomassie blue revealed only minor difference (Fig 3B). The intensity of phosphorylation and especially of ATPdepended phosphoprotein proteolysis were lower in the nuclei and NMs of ascites hepatoma and negligible in normal liver (not shown). As phosphatases are mostly soluble, the pattern of phosphorylation in NM isolated in the presence of proteinase inhibitors and then phosphorylated with $\gamma-\left[{ }^{32} \mathrm{P}\right]$-ATP (Fig 3A, lane 3) was closer to that phosphorylated in whole nuclei. Vanadate which inhibits proteinphosphatases strongly intensified the phosphorylation (Fig 3C).

\section{Detection of phosphotyrosyl-containing NM proteins}

After treatment of polyacrylamide gel with $1 \mathrm{M} \mathrm{NaOH}$ at $40^{\circ} \mathrm{C}$ for $2 \mathrm{~h}$ only two bands of about 180 and $170 \mathrm{kD}$ remained (Fig 4, lane 3). As phosphoserine and phosphothreonine are hydrolysed under these conditions, the remaining bands probably correspond to phosphotyrosyl-containing HMW proteins.

Nevertheless, an error might not be excluded for phosphoamide bonds are also stable to alkaline hydrolysis. That is why we tried to detect phosphotyrosyl-containing 

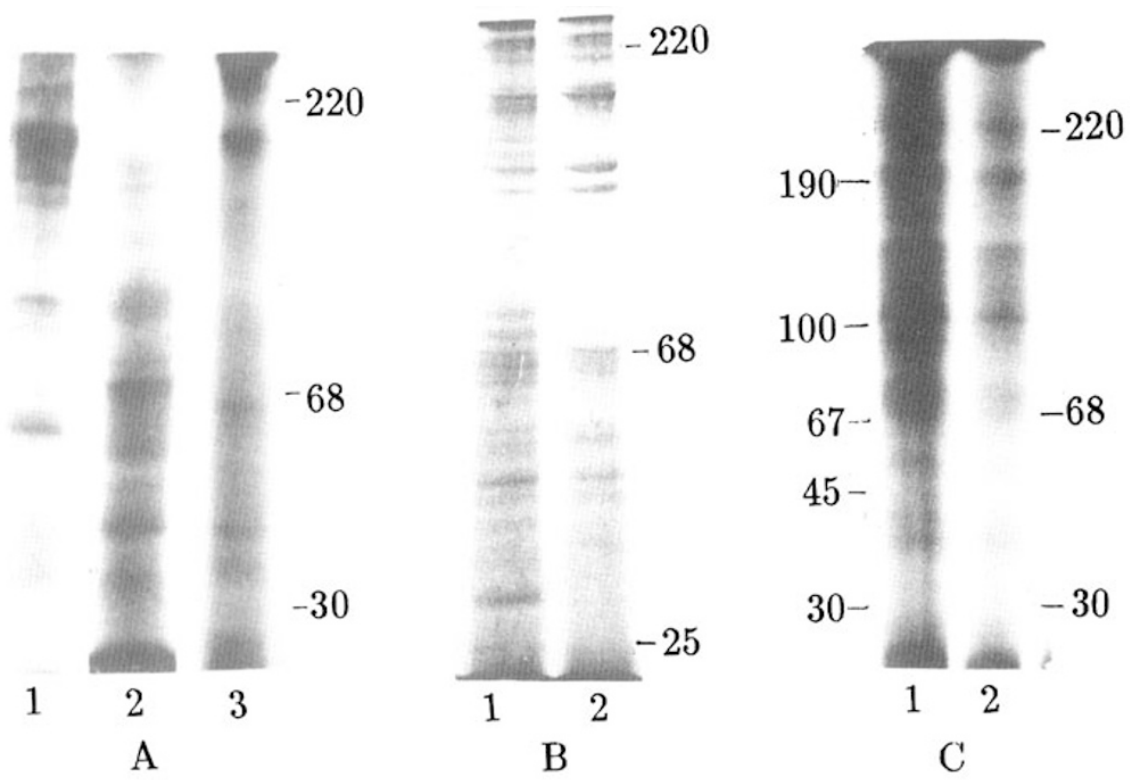

Fig 3. Autoradiograms of rat solid hepatoma $27 \mathrm{NM}$ labeled with ${ }^{32} \mathrm{P}$ at $30^{\circ} \mathrm{C}$ for $30 \mathrm{~min}$. 7.5\% SDS-PAG electrophoresis. A, lane 1, phosphorylation in whole nuclei with ${ }^{32} \mathrm{P}$; the NM was isolated in the presence of $1 \mathrm{mM}$ PMSF and $1 \mathrm{mM}$ DTNB; lane 2, similar experiment but the NM was isolated without inhibitors; lane 3, the NM isolated in the presence of inhibitors was phosphorylated with $\gamma{ }^{32}$ P-ATP. B, Coomassie blue stained electropherograms of the NM phosphorylated in whole nuclei. Lane 1, in the presence of proteinase inhibitors, lane 2, without inhibitors. C, autoradiograms of the NM phosphorylated in whole nuclei in the presence of proteinase inhibitors. Lane 1 , in the presence of $20 \mu \mathrm{M}$ vanadate, lane 2 , without vanadate.

Fig 4. Visualization of rat hepatoma $27 \mathrm{NM}$ alkaline hydrolysis resistant proteins. Lane 1, Coomassie blue stained 7.5\% SDS-PAG electropherogram; lane 2, autoradiogram of a similar gel, lane 3, autoradiogram of a similar gel after treatment with $1 \mathrm{M} \mathrm{NaOH}$ at $40^{\circ} \mathrm{C}$ for $2 \mathrm{~h}$.

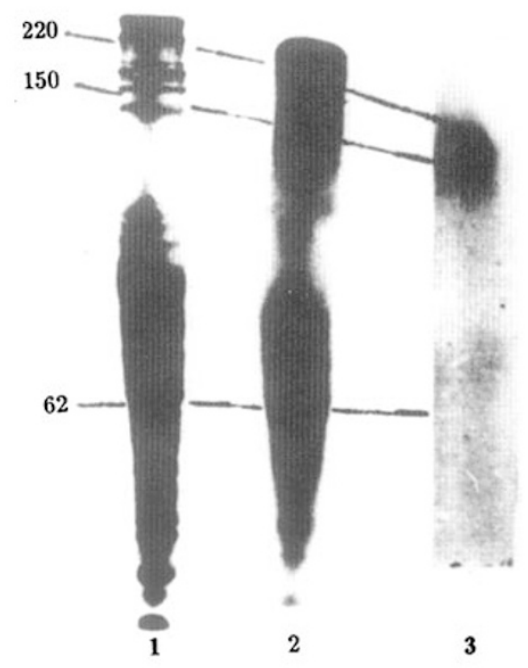


proteins as well with a peroxidase-conjugated monoclonal antibody against phosphotyrosyl residue. After phosphorylation in isolated nuclei of mouse ascites hepatoma 22a, normal mouse liver and ascites Ehrlich carcinoma cells in the presence of proteinase inhibitors, the NMs were isolated and subjected to SDS-PAG electrophoresis. The electropherograms were stained with Coomassie blue and their corresponding counterparts were immunoperoxidase stained after Western blotting.

It is seen (Fig 5) that immunoperoxidase stained HMW (higher than about 120 $\mathrm{kD}$ ) bands were detected in the case of hepatoma 22a (lane 4) and especially of Ehrlich ascites carcinoma (lane 8) but not in normal liver (lane 5). This result confirms the characteristic presence of HMW phosphotyrosyl-containing phosphoproteins in malignant but not in normal (liver) NMs.

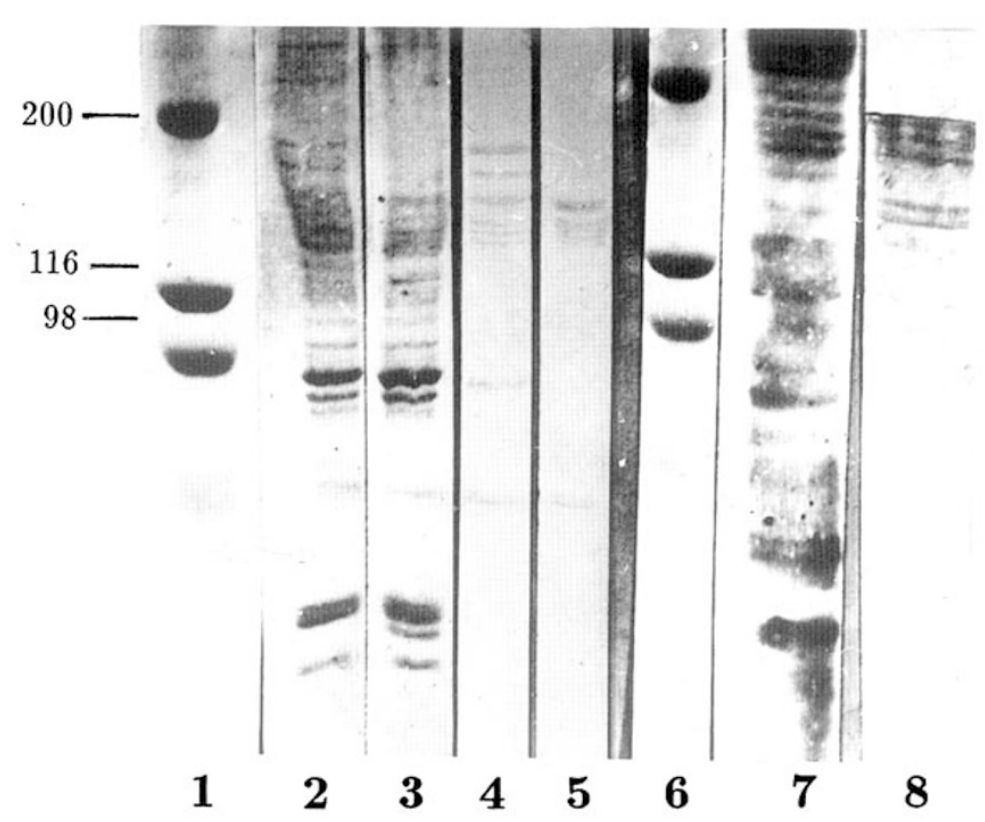

Fig 5. Immunoperoxidase detection of phosphotyrosyl-containing proteins. 7.5\% PAG electrophoresis of NM phosphorylated proteins. Lanes 1, 6, molecular mass standards: myosin-200 kD; B3-galactosidase-116 kD; phosphorylase-89 kD. Lanes 2, 3, 7, Coomassie blue staining: lane 2, mouse ascites hepatoma 22a, lane 3, normal liver; lane 7, Ehrlich ascites carcinoma; lanes 4, lane 5, normal liver, lane 8, Ehrlich ascites photyrosyl residue. Lane 4, hepatoma 22a,22a,lane 5,normal liver,lane 8,Ehrlich ascites carcinoma.

\section{Biosynthesis of tumor NM proteins}

To study the biosynthesis of tumor NM proteins we incubated Zajdela hepatoma ascites with ${ }^{14} \mathrm{C}$-Chlorela protein hydrolysate at $30{ }^{\circ} \mathrm{C}$ for $30 \mathrm{~min}$. Then the hepatoma cells were sedimented, washed and used for nuclei and NM isolation. Disc gels 
Phosphoproteins of tumor nuclear matrix

after electropherophoresis of the NMs were cut into 48 equal slices and in each slice the radioactivity and protein content were measured. Fig 6 shows an intense incorporation of labeled amino acids into NM proteins which was especially prominent in the HMW region, while the protein content of slices did not differ so much.

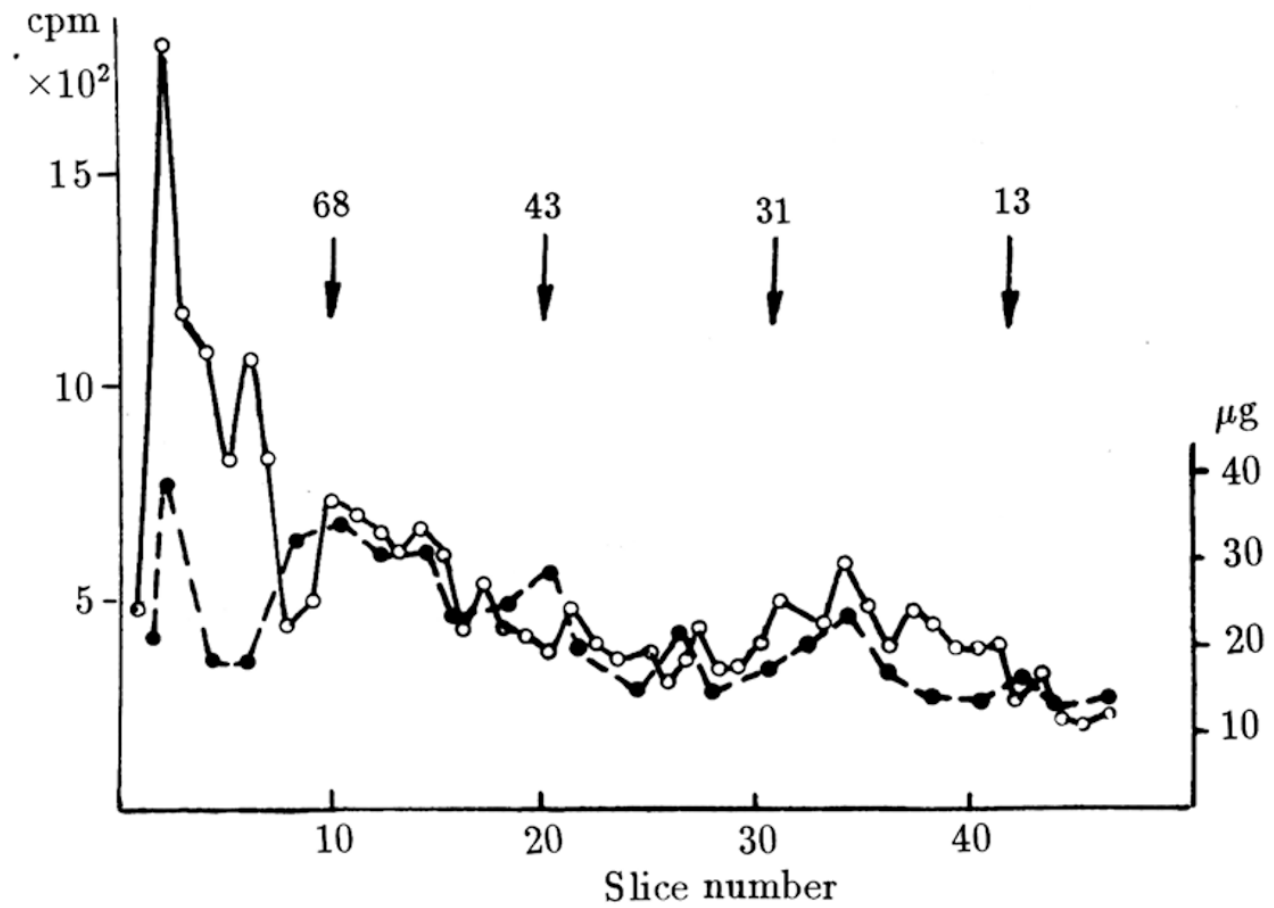

Fig 6. Radioactivity (o) and protein content $(\bullet)$ in 48 slices of $12 \%$ SDS- PAG after electrophoresis of Zajdela ascites hepatoma NM proteins. Cells were incubated with $\left[{ }^{14} \mathrm{C}\right]$ Chlorella protein hydrolysate at $30{ }^{\circ} \mathrm{C}$ for $30 \mathrm{~min}$. Above, molecular mass standards.

Similar experiments were proceeded with the incubation in the presence of CAL (Fig 7). The antibiotic strongly inhibited the incorporation selectively into HMW protein group and slightly into LMW polypeptides, practically without a definite influence on other molecular mass regions.

To ascertain whether this feature was common for other tumor cells, we studied transformed HeLa cell culture in similar experiments in which, however, instead of amino acid mixture, $\left[{ }^{35} \mathrm{~S}\right]$-methionine was used as precursor and its incorporation was monitored by densitometry and autoradiography (Fig 8). In this cell culture CAL also selectively inhibited the incorporation into HMW region with somewhat different pattern which might be due to the use of another precursor and to the variation of temporal conditions. 


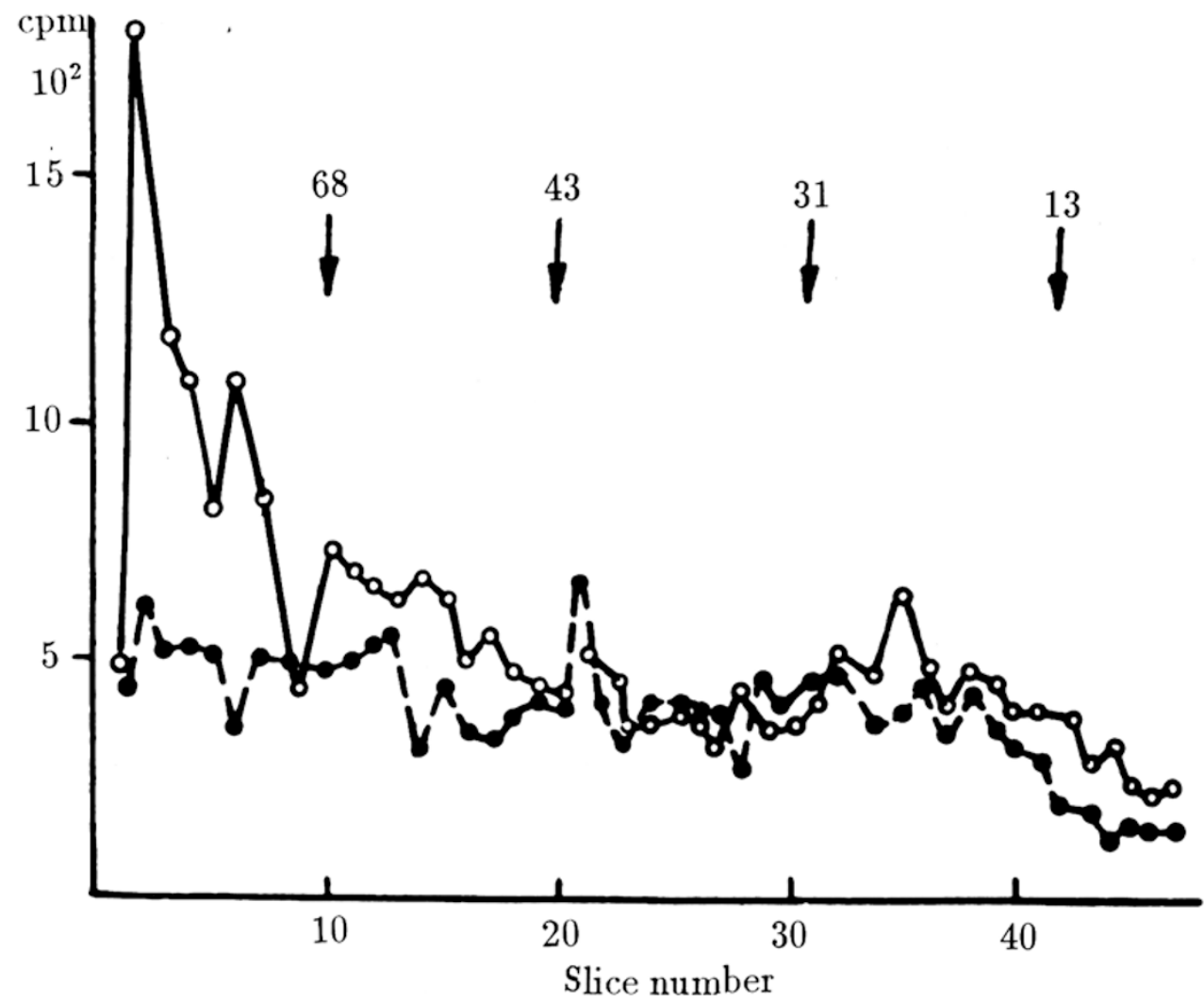

Fig 7. Zajdela ascites hepatoma cells were incubated in ascitic fluid with $\left[{ }^{14} \mathrm{C}\right]$ Chlorella protein hydrolysate at $30{ }^{\circ} \mathrm{C}$ for $30 \mathrm{~min}$. o, without chloramphenicol, $\bullet$, with chloramphenicol. Electropherogram of NM proteins in 12\% SDS-PAAG was cut into 48 slices and in each slice radioactivity was measured. Above, molecular mass standards.

\section{DISCUSSION}

\section{Phosphorylation of the NM proteins}

Our results show an intense incorporation and turnover of phosphate in NM phosphoproteins of hepatoma 27 cells. This feature may apparently be common also to other malignant tumors. It is noteworthy that in rat hepatoma NM the phosphoproteins were preferentially subjected to an intense proteolysis.

A phosphorylation by tyrosyl residue is revealed mainly in two HMW bands in NM proteins of three tumors: solid rat hepatoma 27, mouse ascites hepatoma 22a and mouse Ehrlich ascites carcinoma but not in normal cells (mouse liver). The 
Phosphoproteins of tumor nuclear matrix
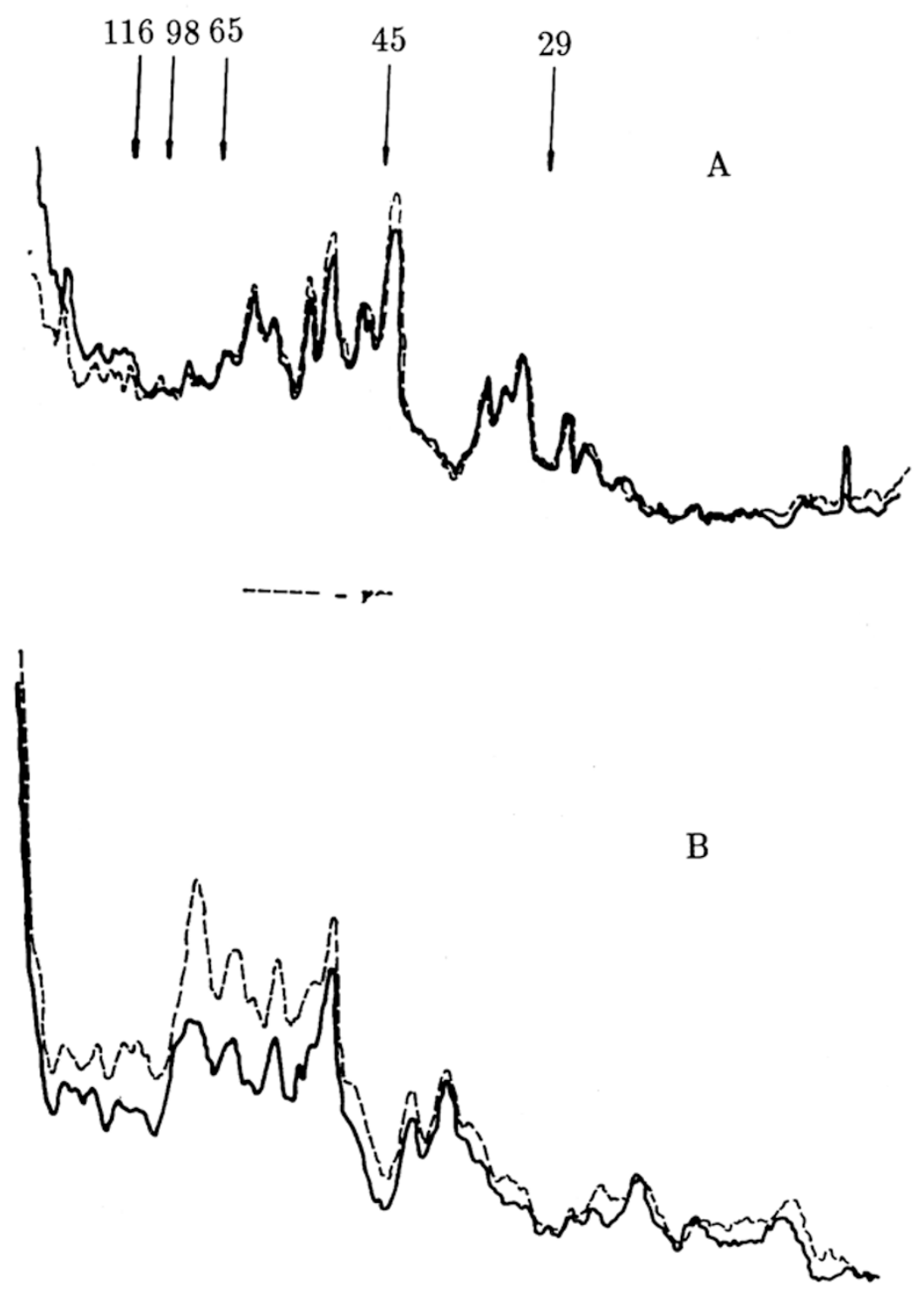

Fig 8. Densitometric tracing of HeLa cell NM. $\left[{ }^{5} \mathrm{~S}\right]-$ methionine-labeled protein electropherograms in 10\% SDS-PAG in lag (stationary) phase. --- control; - incubated with chloramphenicol. A, Coomassie blue staining B, autoradiogram. Above, molecular mass standards.

most interesting feature may be the presence in the NM of two HMW bands of phosphotyrosyl-containing phosphoproteins. These features may be characteristic of malignant growth. However, to ascertain this it is necessary to study also benign tumors and proliferating tissues. 


\section{Biosynthesis of tumor NM proteins}

About 30 - 20 years ago numerous papers reported an active incorporation of labelled amino acids into nuclear proteins. Experiments with isolated nuclei mostly showed that the incorporation, contrary to cytoplasmic counterpart, was inhibited by deoxyribonuclease or CAL but not by ribonuclease [see 27 for summary and discussion].

However, the discovery of ribosomal pathway of protein synthesis in cytoplasm and still more of histone, nucleoplasmin and other nuclear protein synthesis in cytoplasm followed by their transport into nuclei led to a decrease of interest to this question and tacit acknowledgement that biosynthesis of all nuclear proteins proceeded in cytoplasm. Nevertheless, the possibility of intranuclear formation of polypeptides was not disproved.

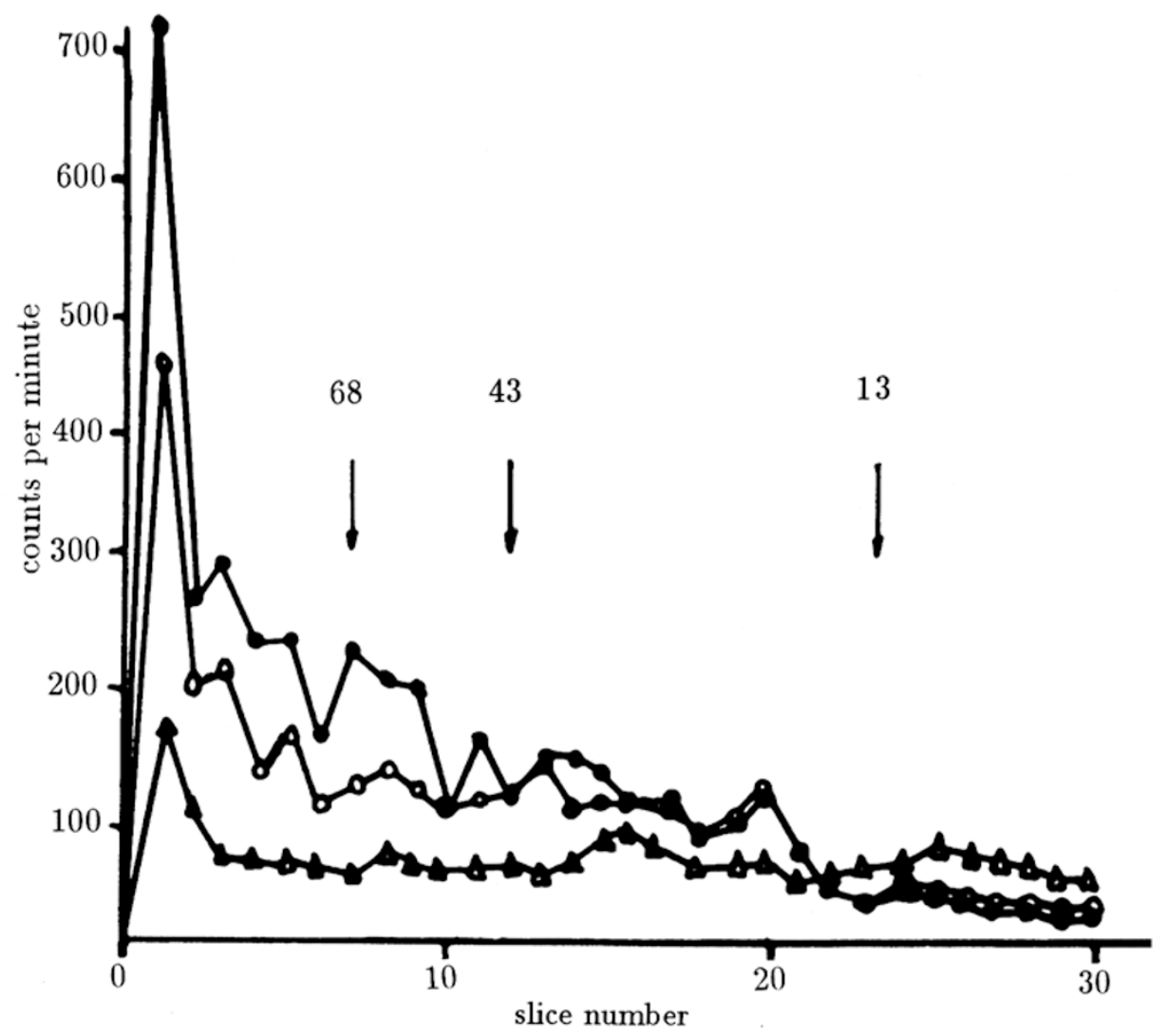

Fig 9. Radioactivity of 30 slices of rat Zajdela ascites hepatoma NM electropherograms after: $\triangle, 15 \mathrm{~min}$. o, $30 \mathrm{~min}$ and $\bullet, 60 \mathrm{~min}$ incubation with $\left[{ }^{14} \mathrm{C}\right]$ Chlorella protein hydrolysate. Above, molecular mass standards. 
Phosphoproteins of tumor nuclear matrix

Our experiments differed from earlier studies by the incorporation of precursors into whole cells and subsequent isolation of nuclei and NMs which apparently lessened artifacts due to contamination of nuclei during the trial.

A selective inhibition of incorporation into HMW proteins by CAL which does not inhibit ribosomal pathway of protein synthesis in eukaryotes may indicate that this protein group of the NM might be synthesised by a special pathway different from other proteins. An interesting feature is a less pronounced inhibition of incorporation into LMW polypeptides (Fig 7) In fact, when the incorporation was measured successively in 15, 30 and $60 \mathrm{~min}$ (Fig 9) it is clearly seen that the radioactivity gradually decreased in LMW area and accumulated in HMW region. Thus, a transfer of label from LMW polypeptides to HMW proteins may be postulated and therefore it may be supposed that some kind of protein processing (polymerization or elongation of primary LMW polypeptides into HMW proteins) might take place. This hypothesis corresponds well with the observation that LMW polypeptides of about $6,000 \mathrm{kD}$ were the primary products of labelled amino acid incorporation into isolated nuclei[28].

\section{ACKNOWLEDGEMENTS}

The authors are indebted to Drs. TV Bulargina and AD Kharitonenkov of Moscow University Biochemistry Department for a gift of monoclonal antibody against phosphotyrosyl-containing proteins.

The work is partly supported by grants of "Perspective Studies in Genetics" and "Russian Foundation of Fundamental Studies".

\section{REFERENCES}

[1] Zbarsky IB, Debov SS. On proteins of the cell nuclei. Doklady Acad Nauk SSSR 1948; 62:795-8.

[2] Zbarsky IB, Debov SS. Protein fractions of the cell nuclei. Biokhimiya 1951; 16:390-5.

[3] Zbarsky IB, Georgiev GP. Cytological characteristics of protein and nucleoprotein fractions of cell nuclei. Biochim Biophys Acta 1959; 32:301-2.

[4] Wang TY, Mayer DT, Thomas LI. A lipoprotein of rat liver nuclei. Exp Cell Res 1953; 4:102-6.

[5] Smetana K, Steele WJ, Busch H. A nuclear ribonucleoprotein network. Exp Cell Res 1963; 31:198-202.

[6] Steele WJ, Busch H. Studies on acidic nuclear proteins of the Walker tumor and liver. Cancer Res 1963; 23:1153-63.

[7] Berezney R, Coffey DS. Identification of a nuclear protein matrix. Biochem Biophys Res Commun $1974 ; 60: 1410-7$.

[8] Buldyaeva TV, Kuzmina SN, Zbarsky IB. Protein composition of rat liver and hepatoma 27 nuclear matrix and residual protein. Doklady Akad Nauk SSSR 1978; 241:1461-4.

[9] Kuzmina SN, Buldyaeva TV, Troitskaya LP, Zbarsky IB. Characterization and fractionation of rat liver nuclear matrix. Eur J Cell Biol 1981; 25:225-32.

[10] Zerlauth G, Wesierska-Gadek J, Sauermann G. Fibronectin observed in the nuclear matrix of HeLa tumor cells. J Cell Sci 1988; 89:415-21.

[11] Filatova LS, Zbarsky IB. Immunochemical detection of some high molecular weight proteins in tumor nuclear matrix. Bull Exp Biol Med 1993; 116:418-20. 
[12] Kleinsmith LJ. Phosphorylation of nonhistone proteins. In: Busch H. ed. The cell nucleus, vol 6 Acad Press: New York 1978; 221-61.

[13] Allen SL, Berezney R. Coffey DS. Phosphorylation of nuclear matrix proteins in isolated rat liver nuclei. Biochem. Biophys Res Commun 1977; 75:111-6.

[14] Sevaljevic L, Brejanovic N, Trajkovic O. Cortisol-induced stimulation of nuclear matrix protein phosphorylation. Mol Biol Rep 1982; 8:226-32.

[15] Taylor SS, Buechler JA, Yonemoto W. cAMP-dependent protein kinase: Framework for a diverse family of regulatory enzymes. Ann Rev Biochem 1990; 59:971-1006.

[16] Hunter T, Cooper JA. Nuclear matrix: A cell cycle-dependent site of increased intranuclear protein phosphorylation. Eur J Biochem 1983; 133:23-9.

[17] Mathews HR, Huebner VD. Nuclear protein kinases. Mol Cell Biochem 1984; 59:81-99.

[18] Sjakste NI, Sjakste TJ. Enzyme activities of the nuclear matrix. Biokhimiya 1994; 59:1663-74.

[19] Maldov DG, Peskin AV, Zbarsky IB. Proteolytic degradation of rat liver, Zajdela hepatoma and hepatoma 22a nuclear matrix proteins in the presence of ATP. Bull Exp Biol Med 1990; 109:558-61.

[20] Blobel G, Potter VR. Nuclei from rat liver; Isolation method that combines purity and high yield. Science 1966; 153:1662-5.

[21] Wold MS, Weinberg DH, Virsbup DM, Li JJ, Kelly Th. Identification of cellular proteins required for simian virus 40 DNA replication. J Biol Chem 1989; 264:2801-9.

[22] Herlan G, Wunderlich F. Isolation of a nuclear protein matrix from Tetrahymena macronuclei. Cytobiologie: 1976; 13:291-6.

[23] Laemmli UK. Cleavage of structural proteins during the assembly of the head of bacteriofage T4. Nature 1970; 227:680-5.

[24] Bonner WM, Laskey RA. A film detection method for tritium-labeled proteins and nucleic acids in polyacrylamide gels. Eur J Biochem 1974; 46:83-8.

[25] Towbin B, Strahelin T, Gordon J. Electrophoretic transfer of proteins from polyacrylamide gels to nitrocellulose sheets: Procedure and some applications. Proc Natl Acad Sci USA 1979; 76:4350-4.

[26] Lowry OH, Rosebrough NJ, Farr AL, Randall RJ. Protein measurement with Folin reagent. J Biol Chem 1951; 193:265-75.

[27] Kuehl L. Nuclear protein synthesis. In: Busch H. ed. The Cell Nucleus. vol 3 Acad Press: New York 1974; 345-78.

[28] Matinyan KS, Umansky SR. Some properties of nuclear protein-synthesising system of eukaryoiic cells. Biokhimiya 1978; 43:111-21.

Received March-20-1998. Revised June-15-1998. Accepted July-6-1998. 